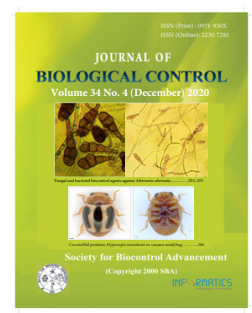

\title{
In vitro efficacy of Beauveria bassiana (Balsamo) Vuillemin against Tetranychus urticae Koch on tuberose
}

\author{
S. ATHISINTHA ${ }^{1 *}$, S. MANIMEGALAI ${ }^{1}$, P. R. NITHYA ${ }^{2}$, R. VISHNUPRIYA $^{1}$ and P. MUTHULAKSHMI ${ }^{3}$ \\ ${ }^{1}$ Department of Agricultural Entomology, Tamil Nadu Agricultural University, Coimbatore - 641003, Tamil Nadu, India \\ ${ }^{2}$ Regional Agricultural Research Station, Kerala Agricultural University, Pattambi - 679306 Kerala, India \\ ${ }^{3}$ Department of Plant Pathology, Tamil Nadu Agricultural University, Coimbatore - 641003, Tamil Nadu, India \\ *Corresponding author E-mail: athisintha007@gmail.com
}

\begin{abstract}
Bio efficacy of virulent isolate of entomopathogenic fungi, Beauveria bassiana (MK918495) was evaluated against two spotted spider mite, Tetranychus urticae on tuberose under pot culture condition at Insectary, Department of Agricultural Entomology, TNAU, Coimbatore. For effective working of any insect pathogen, it is mandatory to develop an effective formulation. Keeping this point in view, in the present study, compatibility of the fungal isolate with two different oils, viz., ground nut and sunflower were tested at different concentrations, viz., 1, 3, 5 and $10 \%$. The results revealed that the groundnut oil was compatible with B. bassiana at all concentrations with respect to colony growth and spore yield compared to sunflower oil which was compatible only at one percent. Based on the results, oil in water and oil based formulations were prepared. At higher concentration of $10 \%$, groundnut oil recorded the radial colony growth of $36.90 \mathrm{~mm}$ diameter and spore yield of $1.2 \times 10^{8}$ spores $\mathrm{mL}^{-1}$. Among the seven formulations (A-G) tested, formulation D which contained surfactant mixture having HLB value of 10.00 (53.33\% Tween 80 and $46.67 \%$ Span 80$)$ formed a better suspension with less flocculation layer and dispersion of conidia in spray fluid and was found to be better as it formed a good emulsion with water by mere shaking. Results of pot culture studies revealed that groundnut oil based fungal formulation was effective with a cumulative mean mite population reduction of $64.98 \%$ followed by crude fungal spore suspension (62.16\%) and both were statistically on par with each other. Standard chemical check, Fenazaquin 10\% EC @ 1.5 mL L-1 recorded significantly highest population reduction of mites $(77.20 \%)$.
\end{abstract}

KEY WORDS: Beauveria bassiana, formulations, pot culture, Tetranychus urticae, tuberose

(Article chronicle: Received: 19-01-2020; Revised: 24-11-2020; Accepted: 02-12-2020)

\section{INTRODUCTION}

Tuberose is an important flower crop grown in tropical regions for their good economic returns throughout the year. In Tamil Nadu, the commercial tuberose growing areas are Dindigul, Coimbatore, Erode, Madurai, Trichy and Ariyalur districts. The damage caused by arthropod pests resulted in significant yield reduction in tuberose. Due to fluctuations in the environmental conditions, red spider mite is emerging as a major pest of tuberose resulting in severe yield reduction (Safeena et al., 2015).

Two spotted spider mite, Tetranychus urticae (Acari:Tetranychidae) is an extremely polyphagous pest that has been reported on more than 900 host species and is a serious pest of at least 150 economically important agricultural and ornamental plants (Jeppson et al., 1975) .
In order to reduce the damage and yield loss caused by mite pests, a large quantity of acaricides has been used which in turn lead to higher level of pesticide residues that may pose severe problem to consumers (Sardana et al., 2005). Due to the short lifespan, faster multiplication rate and indiscriminate application of chemical acaricides, T. urticae developed resistance to many of the acaricides (Croft et al., 1987).

Alternate strategies are the application of predatory mites (Simmonds, 1971). However, insufficient control by predatory mite was reported by Chandler et al. (2005) which lead to search for other eco-friendly methods and in particular, the entomopathogens which are considered safe to human and other non-target arthropods. 
Entomopathogens are gaining increasing importance mainly due to their compatibility with other management strategies under integrated pest management, specific host range and safety to non-target organisms (Saik et al., 1990) and among them, the best one to control sap feeding pest such as $T$. urticae are the entomopathogenic fungi which are capable of infecting mites directly through the integument without necessarily the pathogen being ingested by the insect.

Over 700 different fungal species from at least 90 genera including Beauveria, Metarhizium, Isaria, Lecanicillium, Hirsutella and Entomophthorales are known to be pathogenic to insects (Khachatourians and Qazi, 2008). In the present investigation, oil formulation of B. bassiana MK918495 with an $\mathrm{LC}_{50}$ value of $1.0 \times 10^{6}$ spores $\mathrm{mL}^{-1}$ was evaluated against two spotted spider mite, T. urticae under pot culture conditions at Department of Agricultural Entomology, Tamil Nadu Agricultural University.

\section{MATERIALS AND METHODS}

\section{Mass production of fungal isolates}

The isolate of Beauveria bassiana (MK918495) (Athisintha et al., 2019) was mass multiplied in Potato Dextrose Broth (PDB) for carrying out pot culture studies. $250 \mathrm{~mL}$ of PDB was poured onto round bottom flask of 500 $\mathrm{mL}$ capacity and autoclaved at $121^{\circ} \mathrm{C}$ for 20 minutes. After cooling, one $\mathrm{mL}$ of spore suspension was inoculated into each flask separately and kept in orbital shaker for three days and incubated at room temperature for 10 days. After sporulation, fungal isolates were ground in a mixer and filtered through double layered muslin cloth. The suspension was shaken thoroughly with a drop of Tween 80 in order to disperse the spores in solution. The conidial suspension was vortexed for five minutes to produce a homogenous conidial suspension.

\section{DEVELOPMENT AND STANDARDIZATION OF OIL BASED FORMULATIONS}

\section{Compatibility of Beauveria bassiana (MK918495) with different oils}

The compatibility of selected B. bassiana isolate (MK918495) with different oils was investigated by following poison food technique (Olmert and Kenneth, 1974). The principle involved in this technique is to poison the nutrient medium with a toxicant and then allowing the test fungus to grow on it.

Sterilized PDA media were amended with groundnut and sunflower oil at 1,3,5 and 10\% concentrations. Amended media were poured into $9 \mathrm{~cm}$ diameter Petri dish and allowed for solidification. Two week old B. bassiana (MK918495) grown on PDA medium was cut into $6 \mathrm{~mm}$ disc by using sterile cork borer and the discs were kept in an inverted position onto the centre of well solidified oil amended media plates. Control plate was maintained without amending oil. The plates were kept for incubation at $25 \pm 2 \mathrm{C}$ for fifteen days. Each treatment was replicated thrice. Colony diameter was recorded on seven, ten and fourteen days after inoculation using a ruler (average of two measurements made at right angles), whereas spore count was made from fully sporulated plates on fifteenth day (Visalakshy et al., 2006).

Observations on vegetative growth and sporulation were transferred relative to the control (100) and the product's toxicity $(\mathrm{T})$ values were calculated by following the formula adopted by Alves et al. (2002).

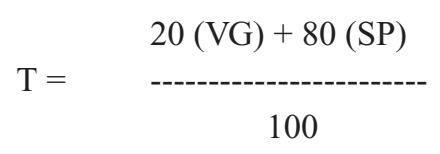

$\mathrm{T}$ - Toxicity value

VG - Vegetative growth; SP - Sporulation

Toxicity range based on $\mathrm{T}$ value

\begin{tabular}{|l|l|}
\hline T value & Toxicity/ Compatibility \\
\hline $0-30$ & Very toxic \\
\hline $31-45$ & Toxic \\
\hline $46-60$ & Moderately toxic \\
\hline$>60$ & Compatible \\
\hline
\end{tabular}

Based on the results of compatibility study, groundnut oil was selected for carrying out the formulation of $B$. bassiana (MK918495).

\section{Oil in water formulation $(0 / w)$}

Oil in water formulation was developed by mixing oil phase with water phase.

Oil phase is constituted by surfactant and groundnut oil each at $1 \%$. Different surfactants viz., Tween 80 and Span 80 alone and in combination were used to formulate oil phase. Surfactant mixture were obtained by mixing Tween 80 and Span 80 in different proportions. Surfactant proportions were fixed based on specific Hydrophilic-Lipophilic Balance (HLB value) according to Griffin (1954). Oil phase was prepared by adding one $\mathrm{mL}$ of the different proportion of surfactant mixture to the groundnut oil (1\%) and kept in a magnetic stirrer for fifteen minutes. $10 \mathrm{~mL}$ of oil phase from different proportion was then fortified in $90 \mathrm{~mL}$ of $B$. bassiana (MK918495) spore suspension $\left(10^{9}\right.$ spores $\left.\mathrm{mL}^{-1}\right)$ and kept in a magnetic stirrer for one hour and left to stand for $2 \mathrm{~h}$. The dispersion of the conidia in the spray mixture was observed every 24 hours for three days. HLB value was arrived using the formula, 


$$
\mathrm{HLB}_{\text {oil }}=\frac{W_{A} X H L B_{A}+W_{B} X H L B_{B}}{W_{A}+W_{B}}
$$

Where $\mathrm{W}_{\mathrm{A}}=$ Amount of first surfactant (Tween 80) required. $\mathrm{W}_{\mathrm{B}}=$ Amount of second surfactant (Span 80) required. $\mathrm{HLB}_{\mathrm{A}}=\mathrm{HLB}$ value of first surfactant. $\mathrm{HLB}_{\mathrm{B}}=\mathrm{HLB}$ value of second surfactant.

$$
\% A=\frac{100 \times\left(x-H L B_{B}\right)}{H L B_{A}-H L B_{B}}
$$

$\% \mathrm{~B}=100-\% \mathrm{~A}$

Where $\% \mathrm{~A}=$ Amount of first surfactant required.

$\% \mathrm{~B}=$ Amount of second surfactant required.

\section{Oil based formulation}

$1 \mathrm{~g}$ of pure conidia $\left(10^{9}\right.$ spores $\left.\mathrm{mL}^{-1}\right)$ was dissolved in $10 \mathrm{~mL}$ of glycerol and to this mixture, $10 \mathrm{~mL}$ of surfactants mixture (Tween 80, Span 80 and combinations of Tween 80 and Span 80 ) was added followed by adding $80 \mathrm{~mL}$ of groundnut oil.

$100 \mathrm{~mL}$ formulation $=1 \mathrm{~g}$ conidia $+10 \mathrm{~mL}$ glycerol + $10 \mathrm{~mL}$ surfactant mixture $+80 \mathrm{~mL}$ of groundnut oil.

The formulations were kept undisturbed for $24 \mathrm{~h}$ at room temperature $\left(25\right.$ to $\left.30^{\circ} \mathrm{C}\right)$. The dispersion of the conidia was observed by adding one $\mathrm{mL}$ of the formulation to $99 \mathrm{~mL}$ of water.

\section{Evaluation of B. bassiana against $T$. urticae under pot culture experiments}

Based on the results of the above experiments, $B$. bassiana (MK918495) and its oil formulation D were tested in comparison with chemical standard, fenazaquin $10 \% \mathrm{EC}$ under pot culture conditions against T. urticae.

The experiment was conducted on potted tuberose plants at the Insectary Unit of Department of Agricultural Entomology, TNAU, Coimbatore in a completely randomized design with five treatments and three replications. Mite population was artificially inoculated on potted tuberose plants and a fortnight after inoculation, the following treatments were imposed and spraying was carried out during evening hours using a hand sprayer. The treatment details are as follows:

Two rounds of treatments were imposed at fortnightly intervals with the help of a hand sprayer. The pre and post

\begin{tabular}{|l|l|}
\hline Treatments & Details \\
\hline T1 & $\begin{array}{l}\text { Groundnut oil based formulation without } \\
\text { fungus }\end{array}$ \\
\hline T2 & $\begin{array}{l}\text { Groundnut oil based fungal formulation @ } \\
10^{8} \text { spores } \mathrm{mL}^{-1}\end{array}$ \\
\hline T3 & Crude fungal suspension @ $10^{8}$ spores $\mathrm{mL}^{-1}$ \\
\hline T4 & Fenazaquin $10 \% \mathrm{EC} @ 1.5 \mathrm{~mL} \mathrm{~L}^{-1}$ \\
\hline T5 & Control (Water spray) \\
\hline
\end{tabular}

treatment observations on live mite population were assessed on $0,3,5,7,10$ and 14 days after application. Three leaves one each from top, middle and bottom region of each plant were assessed for the live mites on the undersurface in an area of $5 \times 2 \mathrm{~cm}$ (length $\mathrm{x}$ breadth). The population was assessed using 10X hand lens. The observations of two consecutive sprays were pooled and cumulative percent reduction of mite population over control was worked out.Statistical analysis were computed using SPSS version 21.0 software for windows.

\section{RESULTS AND DISCUSSION}

Tetranychus urticae became a significant pest of crops because of its capability to develop resistance rapidly against chemical pesticides (Chandler et al., 2005). Therefore, resistance development due to the indiscriminate use of the acaricides and the concerns about public health and environmental issues has necessitated the researchers to unveil the alternative control strategies. Pathogenicity of entomopathogenic fungi viz., Beauveria bassiana, Hirsutella thompsonii and Lecanicillium lecanii against T. urticae were reported (Alves et al., 2002). Among the entomopathogenic fungi, the white muscardine fungus, B. bassiana, the green muscardine fungus, Metarhizium anisopliae and the white halo fungus, L. lecanii are in the forefront (Butt et al., 2001; Chavan et al., 2009).

The successful use of entomopathogenic fungi is mainly dependent on their infectivity and persistence in the environment (Moore and Prior, 1993). Use of oil as an active ingredient or carrier material in the formulation had a clear advantage since oil enhances the virulence and persistence nature of the entomopathogenic fungi against insects compared to other formulations (Prior et al., 1988; Bateman et al., 1993).

Key factors which played a major role in the success of any formulation of entomopathogenic fungi included the 
proper selection of suitable carrier and additive materials which could enhance the virulence and viability of the spores during the storage period. Since, long term storage without loss in virulence is one of the essential attribute of a biocontrol agent, the present study was carried out to develop oil based formulation of B. bassiana (MK918495).

Compatibility of selected $B$. bassiana isolate (MK918495) with two different oils, viz., groundnut and sunflower oil were tested under in vitro condition (Figure 1). Experimental results showed significant variation in compatibility of B. bassiana (MK918495) with these two oils at different concentration (Table 1). Based on the T-value, groundnut oil was classified as compatible at all concentrations with respect to colony growth and spore yield. The $\mathrm{T}$ value for groundnut oil was in the range of 88.10 , $79.64,67.55$ and 63.05 at $1,3,5$ and $10 \%$ concentrations respectively and it was found to be compatible (D) with $B$. bassiana MK918495. In contrast, sunflower oil was found to be compatible with B. bassiana (MK918495) only at $1 \%$ concentration with $\mathrm{T}$ value of 60.06 whereas with other concentrations, viz., 3,5 and $10 \%$, it recorded $\mathrm{T}$ value of $55.71,47.61,43.47$ showing toxicity range from toxic (B) to moderately toxic $(\mathrm{C})$.

With respect to colony growth and spore yield, a decreased trend was observed with increase in concentration of oils. Groundnut oil recorded the highest colony growth of $41.60 \mathrm{~mm}$ diameter and spore yield of $1.8 \times 10^{8}$ spores $\mathrm{mL}^{-1}$ at $1 \%$ concentration after 15 days of inoculation. At $10 \%$ concentration, it recorded the colony growth of 36.90 $\mathrm{mm}$ diameter and spore yield of $1.2 \times 10^{8}$ spores $\mathrm{mL}^{-1}$. Sunflower oil recorded lesser colony growth and spore yield ranging from 31.80 to $27.70 \mathrm{~mm}$ diameter and $1.2 \times 10^{8}$ spores $\mathrm{mL}^{-1}$ to $0.2 \times 10^{8}$ spores $\mathrm{mL}^{-1}$ respectively at different concentrations compared to groundnut oil. PDA media without oil recorded colony growth of $42.60 \mathrm{~mm}$ diameter and $2.1 \times 10^{8}$ spores $\mathrm{mL}^{-1}$. Since the media amended with groundnut oil at different concentration and the media without oil were found to be statistically on par, groundnut oil at $1 \%$ was used for development of oil in water formulation and groundnut oil at $8 \%$ was used for oil based formulations. Compatibility studies conducted revealed that groundnut oil was more compatible with B. bassiana (MK918495) over sunflower oil when tested at different concentrations (Figure 4). Colony growth and spore yield were found to decrease with increase in concentration of oil. Gatarayiha et al., (2010) attributed that spore yield and mycelial growth were considered as factors for testing the compatibility of oils with entomopathogenic fungus. The same was proved in present study wherein groundnut oil recorded the maximum colony growth and spore yield indicating its compatibility with $B$. bassiana (MK918495).
Based on the results of studies on compatibility, groundnut oil at $1 \%$ was selected and used for developing oil in water formulation. The different surfactants, viz., Tween 80 , Span 80 and their combinations were tested in order to get a good emulsion. Wide number of surfactants is available in market and suitable one need to be selected for which HLB systems are useful.

Among the tested combinations of surfactants with groundnut oil and fungal spore, the final product after a period of two hours showed sedimentation (Figure 2) which indicated the formation of poor emulsion (Table 3). Since the aqueous formulations were stable only for a shorter period of time, steps were taken to develop oil based formulation. The necessity for developing formulation other than aqueous was indicated by Kaaya and Hedimbi (2012). They reported that oil formulated conidia were found to provide thermotolerance to the conidia and enhanced its effectiveness even under low humidity.

Accordingly in the present investigation, efforts were made for developing oil based formulation. The success of oil-based formulation mainly depended on the effective combination of emulsifier, dispersion and suspension particles at right proportion. Key factors contributing for a good formulation includes purity and compatibility of the oil, effective surfactant, Hydrophilic-Liphophilic Balance (HLB) and suitable dispersing agent.

Oil based formulation was prepared by dissolving 1 $\mathrm{g}$ of pure conidia $\left(10^{9}\right.$ spores $\left.\mathrm{mL}^{-1}\right)$ in $10 \mathrm{~mL}$ of glycerol followed by addition of $10 \mathrm{~mL}$ of various surfactants, viz., Tween 80, Span 80 and their combinations (Table 2) and 80 $\mathrm{mL}$ groundnut oil. Different combinations were observed for sedimentation after 24 hours. Gillespie and Crawford (1986) reported that germination and viability of B. bassiana, $M$. anisopliae and Paecilomyces farinosus were enhanced by the addition of glycerol under field conditions. In the present study, glycerol was used for the development of oil based formulation along with surfactant and oil. This might have contributed for the better efficacy of oil based fungal formulation against $T$. urticae under pot culture conditions.

Among various combinations, formulation D which contained surfactant mixture having HLB value of 10.00 (53.33\% Tween 80 and $46.67 \%$ Span 80 ) formed a better suspension with less sedimentation (Figure 3) compared to other treatments containing different proportion of surfactant mixture (Table 4). Dispersion of conidia in spray fluid was checked by adding one $\mathrm{mL}$ of the formulation to $99 \mathrm{~mL}$ of water and it was found to be better for formulation $\mathrm{D}$ which formed a good emulsion with water. 
HLB concept states that the surfactants having low HLB tend to be oil soluble and the one with high values tend to be water soluble. However, this does not always seem to be the same in all situations. In our study, surfactant mixture having high HLB value (10.00) exhibited high solubility which corroborates with the findings of Gadhave (2014) who reported that surfactants with same HLB value may exhibit different solubility characteristics.

Further, formulation $D$ was evaluated for their efficacy under pot culture against $T$. urticae on tuberose in comparison with crude fungal spore suspension and standard chemical check, fenazaquin 10\% EC. The plants sprayed with groundnut oil based formulation without fungus did not show any symptoms of phytotoxicity thus ensuring that groundnut oil can be used as an ingredient for developing formulations of entomopathogenic fungi.

Pre-treatment count of T. urticae was in the range of 8.84 to 11.52 numbers per plant and was statistically nonsignificant. After first round of spraying, the standard chemical check, fenazaquin 10\% EC (1 mL L-1) recorded significantly lowest mite population of $7.12,4.32,3.20$, 2.62 and 4.72 numbers per plant at 3, 5, 7, 10 and 14 days after treatment with highest population reduction of $69.74 \%$ followed by groundnut oil based formulation of $B$. bassiana MK918495 (55.63\%) and crude fungal suspension (52.42\%). At 14 days after application, fenazaquin recorded significant lowest population of 4.72 numbers per plant followed by groundnut oil based fungal formulation (8.26 numbers/plant) and crude fungal suspension (7.60 numbers/plant) and both were on par with each other. The population of mites were significantly higher in groundnut based oil formulation without fungus (16.25 numbers/plant).

After second round of spraying, fenazaquin recorded significantly lowest population $(3.21,2.63,2.41,1.97$ and 6.21 numbers/plant at 3, 5, 7, 10 and 14 days after spraying) and highest percent reduction in population $(80.16 \%)$ followed by groundnut oil based fungal formulation $(7.92,6.29,4.62,4.10$ and 7.23 numbers/plant) with $74.33 \%$ reduction and crude fungal suspension $(7.12,6.23,5.62,3.26$ and 5.32 numbers/ plant) with population reduction of $71.90 \%$. At 14 days after application, fenazaquin recorded significantly lowest population of 6.25 numbers per plant followed by groundnut oil based fungal formulation (7.23 numbers/plant) and crude fungal suspension (5.32 numbers/plant).

At the end of second round of application, groundnut oil based formulation of B. bassiana (MK918495) was found to be effective against $T$. urticae with a cumulative mean mite population of reduction of $64.98 \%$ reduction followed by the crude fungal spore suspension $(62.16 \%)$ and both were statistically on par with each other. However, the standard chemical check recorded the significantly highest population reduction $(77.20 \%)$. It was observed that the population was reduced significantly upto ten days after each round of spraying and increased thereafter.

The results showed that both the groundnut oil based fungal formulation and the crude fungal suspension were statistically on par with each other and recorded the cumulative mean mite population reduction of 61.18 and $58.00 \%$ respectively (Figure 5). Manivannan et al., (2018) reported that B. bassiana recorded $48.33 \%$ mortality of cotton leafhopper under pot culture experiment. Prithiva et al. (2017) reported that oil formulation of $B$. bassiana recorded $45.86 \%$ reduction in population of Bemisia tabaci under microplot conditions. The better efficacy of formulation over crude suspension was reported by several authors (Agarwal et al., 2012; Alves et al., 2002; Batta, 2003). However, no significant difference was observed in the present investigation. This might be due to spraying of freshly prepared conidial suspension and existence of favorable environment for establishment of EPF. The favorable environment might have contributed for enhanced adhesion, germination and penetration of conidia. However, oil based formulation might prove better than crude suspension under long term storage conditions.

Formulating the entomofungal pathogens in oil enhanced their effectiveness by means of increasing adhesion, spreading the inoculums and probably interfering with the defensive nature of the cuticle thereby facilitating the easy penetration of the germinated spores (Prior et al., 1988) and the same was proved by many authors (Chavan et al., 2009; Gatarayiha et al., 2010; Luz and Batagin, 2005).

Eco-friendly management of mite pest is the need of the hour and the present study supports this concept. B. bassiana (MK918495) was found effective against two spotted spider mite, T. urticae under in vitro condition. Groundnut oil based formulation containing $10^{8}$ spores $\mathrm{mL}^{-1}$ was found promising under pot culture conditions against $T$. urticae on tuberose. In this study, with two sprays mite population was brought under ETL. Hence further spraying was not taken up. As the crop is perennial, need based application of beauveria can be carried out when mite infestation is observed. Testing the shelf life and stability of the developed oil formulation will add value to the formulation. Further research on temperature and UV tolerance may pave way for developing a commercial formulation with good persistence in the environment. 
Efficacy of Beauveria bassiana against Tetranychus urticae on tuberose

Table 1. Compatibility of Beauveria bassiana (MK918495) with oil

\begin{tabular}{|c|c|c|c|c|c|c|c|c|c|c|c|c|}
\hline \multirow{3}{*}{ Treatments } & \multicolumn{12}{|c|}{ Concentration of oil (\%) } \\
\hline & \multicolumn{3}{|c|}{1} & \multicolumn{3}{|c|}{3} & \multicolumn{3}{|c|}{5} & \multicolumn{3}{|c|}{10} \\
\hline & VG & SP & $\mathbf{T} *$ & VG & SP & $\mathbf{T}^{*}$ & VG & SP & $\mathbf{T}^{*}$ & VG & SP & $T^{*}$ \\
\hline $\begin{array}{l}\text { Groundnut } \\
\text { oil }\end{array}$ & $\begin{array}{c}41.60 \\
(97.65)\end{array}$ & $\begin{array}{c}1.80 \\
(85.71)\end{array}$ & $\begin{array}{c}88.10 \\
\text { (D) }\end{array}$ & $\begin{array}{c}39.80 \\
(93.42)\end{array}$ & $\begin{array}{c}1.60 \\
(76.19)\end{array}$ & $\begin{array}{c}79.64 \\
\text { (D) }\end{array}$ & $\begin{array}{c}38.40 \\
(90.14)\end{array}$ & $\begin{array}{c}1.40 \\
(71.36)\end{array}$ & $\begin{array}{c}67.55 \\
\text { (D) }\end{array}$ & $\begin{array}{c}36.90 \\
(86.61)\end{array}$ & $\begin{array}{c}1.20 \\
(57.14)\end{array}$ & $\begin{array}{c}63.05 \\
\text { (D) }\end{array}$ \\
\hline $\begin{array}{c}\text { Sunflower } \\
\text { oil }\end{array}$ & $\begin{array}{c}31.80 \\
(74.64)\end{array}$ & $\begin{array}{c}1.20 \\
(57.14)\end{array}$ & $\begin{array}{l}60.06 \\
\text { (D) }\end{array}$ & $\begin{array}{c}29.40 \\
(69.01)\end{array}$ & $\begin{array}{c}1.10 \\
(52.38)\end{array}$ & $\begin{array}{l}55.71 \\
(\mathrm{C})\end{array}$ & $\begin{array}{c}28.40 \\
(66.67)\end{array}$ & $\begin{array}{c}0.90 \\
(42.85)\end{array}$ & $\begin{array}{c}47.61 \\
(\mathrm{C})\end{array}$ & $\begin{array}{c}27.70 \\
(65.00)\end{array}$ & $\begin{array}{c}0.80 \\
(38.09)\end{array}$ & $\begin{array}{c}43.47 \\
\text { (B) }\end{array}$ \\
\hline Control & $\begin{array}{c}42.60 \\
(100.00)\end{array}$ & $\begin{array}{c}2.10 \\
(100.00)\end{array}$ & & $\begin{array}{c}42.60 \\
(100.00)\end{array}$ & $\begin{array}{c}2.10 \\
(100.00)\end{array}$ & & $\begin{array}{c}42.60 \\
(100.00)\end{array}$ & $\begin{array}{c}2.10 \\
(100.00)\end{array}$ & & $\begin{array}{c}42.60 \\
(100.00)\end{array}$ & $\begin{array}{c}2.10 \\
(100.00)\end{array}$ & \\
\hline
\end{tabular}

VG - Vegetative growth $(\mathrm{mm}), \mathrm{SP}-$ Sporulation $\left(\mathrm{x} 10^{8}\right.$ spores $\left.\mathrm{mL}^{-1}\right)$

Figures in parentheses are values relative to control $(100 \%)$

*Classification based on formula: $\mathrm{T}=(20 \mathrm{VG}+80 \mathrm{SP}) / 100$

A- Very Toxic (T value 0-30), B - Toxic (T value 31- 45), C - Moderately toxic ( $\mathrm{T}$ value 46-60), D - Compatible ( $\mathrm{T}$ value $>60)$

Table 2. Selection of surfactant combination based on Hydrophilic-Lipophilic Balance (HLB) value for a good emulsion (Oil in water formulation)

\begin{tabular}{|l|l|l|l|l|l|l|l|}
\hline Formulation & HLB value & $\begin{array}{l}\text { Tween 80 } \\
\mathbf{( \% )}\end{array}$ & Span 80 (\%) & $\begin{array}{l}\text { Surfactant } \\
\text { combination } \\
(\mathbf{m L})\end{array}$ & $\begin{array}{l}\text { Groundnut } \\
\text { oil } \\
(\mathbf{m L})\end{array}$ & $\begin{array}{l}\text { Spore } \\
\text { suspension } \\
(\mathbf{m L})\end{array}$ & Description* \\
\hline A & 4.3 & - & 100 & 10 & 10 & 80 & Negligible \\
\hline B & 8 & 34.57 & 65.43 & 10 & 10 & 80 & Negligible \\
\hline C & 9 & 43.92 & 56.08 & 10 & 10 & 80 & Negligible \\
\hline D & 10 & 53.33 & 46.67 & 10 & 10 & 80 & Negligible \\
\hline E & 12 & 71.96 & 28.04 & 10 & 10 & 80 & Poor \\
\hline F & 14 & 90.65 & 9.35 & 10 & 10 & 80 & Poor \\
\hline G & 15 & 100 & - & 10 & 10 & 80 & Poor \\
\hline
\end{tabular}

Quantity of formulation $=100 \mathrm{~mL}$

*Based on sedimentation 
Athisintha et al.

Table 3. Selection of surfactant combination based on Hydrophilic-Lipophilic Balance (HLB) value for a good emulsion (Oil formulation)

\begin{tabular}{|l|l|l|l|l|l|l|l|}
\hline Formulation & HLB value & Tween 80 (\%) & Span 80 (\%) & $\begin{array}{l}\text { Surfactant } \\
\text { combination } \\
(\mathbf{m L})\end{array}$ & $\begin{array}{l}\text { Groundnut oil } \\
(\mathbf{m L})\end{array}$ & $\begin{array}{l}\text { Glycerol } \\
(\mathbf{m L})\end{array}$ & Description* \\
\hline A & 4.3 & - & 100 & 10 & 80 & 10 & Negligible \\
\hline B & 8 & 34.57 & 65.43 & 10 & 80 & 10 & Negligible \\
\hline C & 9 & 43.92 & 56.08 & 10 & 80 & 10 & Negligible \\
\hline D & 10 & 53.33 & 46.67 & 10 & 80 & 10 & $\begin{array}{l}\text { Good } \\
\text { suspension }\end{array}$ \\
\hline E & 12 & 71.96 & 28.04 & 10 & 80 & 10 & Poor \\
\hline F & 14 & 90.65 & 9.35 & 10 & 80 & 10 & Poor \\
\hline G & 15 & 100 & - & 10 & 80 & 10 & Poor \\
\hline
\end{tabular}

Quantity of formulation $=100 \mathrm{~mL}$

Dose of fungus $=1 \mathrm{~g}$ of pure conidia for $100 \mathrm{~mL}$ of formulation $\left(10^{9}\right.$ spores $\left.\mathrm{mL}^{-1}\right)$

*Based on sedimentation

Table 4. Pot culture studies on the efficacy of Beauveria bassiana (MK918495) against Tetranychus urticae on tuberose (First spray)

\begin{tabular}{|c|c|c|c|c|c|c|c|c|}
\hline \multirow{2}{*}{ Treatments } & \multirow{2}{*}{$\begin{array}{l}\text { PTC } \\
\text { (No. of } \\
\text { mites / } \\
\text { plant) }\end{array}$} & \multicolumn{5}{|c|}{ Number of mites / plant at different days after spraying } & \multirow{2}{*}{ Mean } & \multirow{2}{*}{$\begin{array}{l}\text { Reduc- } \\
\text { tion over } \\
\text { control } \\
(\%)\end{array}$} \\
\hline & & 3 & 5 & 7 & 10 & 14 & & \\
\hline $\begin{array}{l}\text { Groundnut oil based } \\
\text { formulation without } \\
\text { fungus }\end{array}$ & $\begin{array}{l}11.52 \\
(3.84)\end{array}$ & $\begin{array}{l}12.23^{\mathrm{b}} \\
(3.57)\end{array}$ & $\begin{array}{l}13.02^{\mathrm{c}} \\
(3.68)\end{array}$ & $\begin{array}{l}13.95^{\mathrm{c}} \\
(3.80)\end{array}$ & $\begin{array}{l}14.26^{\mathrm{c}} \\
(3.84)\end{array}$ & $\begin{array}{l}16.25^{\mathrm{c}} \\
(4.09)\end{array}$ & 13.94 & 4.03 \\
\hline $\begin{array}{l}\text { Groundnut oil based } \\
\text { fungal formulation }\end{array}$ & $\begin{array}{l}8.84 \\
(3.06)\end{array}$ & $\begin{array}{l}7.91^{\mathrm{a}} \\
(2.77)\end{array}$ & $\begin{array}{l}6.92^{\mathrm{b}} \\
(2.72)\end{array}$ & $\begin{array}{l}6.23^{\mathrm{b}} \\
(2.59)\end{array}$ & $\begin{array}{l}5.96^{\mathrm{b}} \\
(2.54)\end{array}$ & $\begin{array}{l}8.26^{\mathrm{b}} \\
(2.76)\end{array}$ & 6.45 & 55.63 \\
\hline $\begin{array}{l}\text { Crude fungal suspen- } \\
\text { sion }\end{array}$ & $\begin{array}{l}9.83 \\
(3.21)\end{array}$ & $\begin{array}{l}7.62^{\mathrm{a}} \\
(2.85)\end{array}$ & $\begin{array}{l}7.12^{\mathrm{b}} \\
(2.75)\end{array}$ & $\begin{array}{l}6.21^{\mathrm{b}} \\
(2.59)\end{array}$ & $\begin{array}{l}3.68^{\mathrm{b}} \\
(2.03)\end{array}$ & $\begin{array}{l}7.60^{\mathrm{b}} \\
(2.85)\end{array}$ & 6.91 & 52.42 \\
\hline $\begin{array}{l}\text { Fenazaquin } 10 \% \text { EC } \\
\left(1.5 \mathrm{~mL} \mathrm{~L}^{-1}\right)\end{array}$ & $\begin{array}{l}11.52 \\
(3.46)\end{array}$ & $\begin{array}{l}7.12^{\mathrm{a}} \\
(2.76)\end{array}$ & $\begin{array}{l}4.32^{\mathrm{a}} \\
(2.19)\end{array}$ & $\begin{array}{l}3.20^{\mathrm{a}} \\
(1.89)\end{array}$ & $\begin{array}{l}2.62^{\mathrm{a}} \\
(1.73)\end{array}$ & $\begin{array}{l}4.72^{\mathrm{a}} \\
(2.20)\end{array}$ & 4.40 & 69.74 \\
\hline Control & $\begin{array}{l}11.12 \\
(3.39)\end{array}$ & $\begin{array}{l}13.21^{\mathrm{b}} \\
(3.69)\end{array}$ & $\begin{array}{l}13.61^{\mathrm{c}} \\
(3.75)\end{array}$ & $\begin{array}{l}14.01^{\mathrm{c}} \\
(3.80)\end{array}$ & $\begin{array}{l}15.67^{\mathrm{c}} \\
(3.94)\end{array}$ & $\begin{array}{l}16.14^{\mathrm{c}} \\
(5.03)\end{array}$ & 14.53 & \\
\hline $\mathrm{SE}(\mathrm{d})$ & - & 0.13 & 0.14 & 0.20 & 0.22 & 0.30 & - & - \\
\hline $\mathrm{CD}(0.05)$ & NS & 0.29 & 0.31 & 0.43 & 0.48 & 0.65 & - & - \\
\hline
\end{tabular}

Dose of fungus - $10^{8}$ spores $\mathrm{mL}^{-1}$

PTC- Pretreatment count; Figures in the parentheses are $\sqrt{x+0.5}$ transformed values

In a column, means followed by a common letter ( $s$ ) are not significantly different at $\mathrm{P}=0.05$ by LSD

NS - Non - significant 
Efficacy of Beauveria bassiana against Tetranychus urticae on tuberose

Table 5. Pot culture studies on the efficacy of Beauveria bassiana (MK918495) against Tetranychus urticae on tuberose (Second spray)

\begin{tabular}{|c|c|c|c|c|c|c|c|c|c|c|}
\hline \multirow{2}{*}{ Treatments } & \multirow{2}{*}{$\begin{array}{l}\text { PTC } \\
\text { (No. of } \\
\text { mites/plant) }\end{array}$} & \multicolumn{5}{|c|}{ No. of mites/plant at different days after spraying } & \multirow{2}{*}{ Mean } & \multirow{2}{*}{\begin{tabular}{|l|} 
Reduc- \\
tion over \\
control \\
$(\%)$ \\
\end{tabular}} & \multirow{2}{*}{$\begin{array}{l}\text { Pooled } \\
\text { mean }\end{array}$} & \multirow{2}{*}{$\begin{array}{l}\text { Cumulative } \\
\text { reduction } \\
\text { over control } \\
(\%) \\
\end{array}$} \\
\hline & & 3 & 5 & 7 & 10 & 14 & & & & \\
\hline $\begin{array}{l}\text { Groundnut oil } \\
\text { based formula- } \\
\text { tion without } \\
\text { fungus }\end{array}$ & $\begin{array}{l}16.25 \\
(4.09)\end{array}$ & $\begin{array}{l}17.42^{\mathrm{c}} \\
(4.23)\end{array}$ & $\begin{array}{l}18.46^{\mathrm{c}} \\
(4.35)\end{array}$ & $\begin{array}{l}20.49^{c} \\
(4.58)\end{array}$ & $\begin{array}{l}22.76^{\mathrm{c}} \\
(4.82)\end{array}$ & $\begin{array}{l}21.46^{c} \\
(4.68)\end{array}$ & 20.12 & 6.31 & $\begin{array}{l}17.03^{c} \\
(4.19)\end{array}$ & 5.17 \\
\hline $\begin{array}{l}\text { Groundnut oil } \\
\text { based fungal } \\
\text { formulation }\end{array}$ & $\begin{array}{l}8.26 \\
(2.76)\end{array}$ & $\begin{array}{l}7.92^{\mathrm{b}} \\
(2.90)\end{array}$ & $\begin{array}{l}6.29^{\mathrm{b}} \\
(2.61)\end{array}$ & $\begin{array}{l}4.62^{\mathrm{b}} \\
(2.25)\end{array}$ & $\begin{array}{l}4.10^{\mathrm{b}} \\
(2.13)\end{array}$ & $\begin{array}{l}7.23^{\mathrm{b}} \\
(2.77)\end{array}$ & 5.51 & 74.33 & $\begin{array}{l}5.97^{\mathrm{b}} \\
(2.64)\end{array}$ & 64.98 \\
\hline $\begin{array}{l}\text { Crude fungal } \\
\text { suspension }\end{array}$ & $\begin{array}{l}7.60 \\
(2.86) \\
\end{array}$ & $\begin{array}{l}7.12^{\mathrm{b}} \\
(2.76) \\
\end{array}$ & $\begin{array}{l}6.23^{\mathrm{b}} \\
(2.59) \\
\end{array}$ & $\begin{array}{l}5.62^{\mathrm{b}} \\
(2.46) \\
\end{array}$ & $\begin{array}{l}3.26^{\mathrm{b}} \\
(1.94)\end{array}$ & $\begin{array}{l}5.32^{\mathrm{b}} \\
(2.41) \\
\end{array}$ & 6.03 & 71.90 & $\begin{array}{l}6.42^{\mathrm{b}} \\
(2.55)\end{array}$ & 62.16 \\
\hline $\begin{array}{l}\text { Fenazaquin } 10 \\
\% \text { EC } \\
\left(1.5 \mathrm{~mL} \mathrm{~L}^{-1}\right)\end{array}$ & $\begin{array}{l}4.72 \\
(2.20)\end{array}$ & $\begin{array}{l}3.21^{\mathrm{a}} \\
(1.89)\end{array}$ & $\begin{array}{l}2.63^{\mathrm{a}} \\
(1.74)\end{array}$ & $\begin{array}{l}2.41^{\mathrm{a}} \\
(1.69)\end{array}$ & $\begin{array}{l}1.97^{\mathrm{a}} \\
(1.57)\end{array}$ & $\begin{array}{l}6.25^{\mathrm{a}} \\
(2.57)\end{array}$ & 3.29 & 84.65 & $\begin{array}{l}3.84^{\mathrm{a}} \\
(2.08)\end{array}$ & 77.20 \\
\hline Control & $\begin{array}{l}16.14 \\
(4.08) \\
\end{array}$ & $\begin{array}{l}17.43^{\mathrm{c}} \\
(4.23) \\
\end{array}$ & $\begin{array}{l}19.72^{\mathrm{c}} \\
(4.49) \\
\end{array}$ & $\begin{array}{l}20.73^{d} \\
(4.61) \\
\end{array}$ & $\begin{array}{l}23.75^{\mathrm{d}} \\
(4.92) \\
\end{array}$ & $\begin{array}{l}25.73^{\mathrm{d}} \\
(5.12) \\
\end{array}$ & 21.47 & & $\begin{array}{l}18.00^{c} \\
(4.30) \\
\end{array}$ & \\
\hline $\mathrm{SE}(\mathrm{d})$ & - & 0.18 & 0.18 & 0.18 & 0.16 & 0.10 & - & - & 0.19 & \\
\hline C.D. $(0.05)$ & NS & 0.41 & 0.41 & 0.39 & 0.35 & 0.22 & - & - & 0.41 & \\
\hline
\end{tabular}

Dose of fungus $-10^{8}$ spores $\mathrm{mL}^{-1}$

PTC- Pretreatment count; Figures in parentheses are $\sqrt{x+0.5}$ transformed values

In a column, means followed by a common letter (s) are not significantly different at $\mathrm{P}=0.05$ by LSD

NS - Non - significant

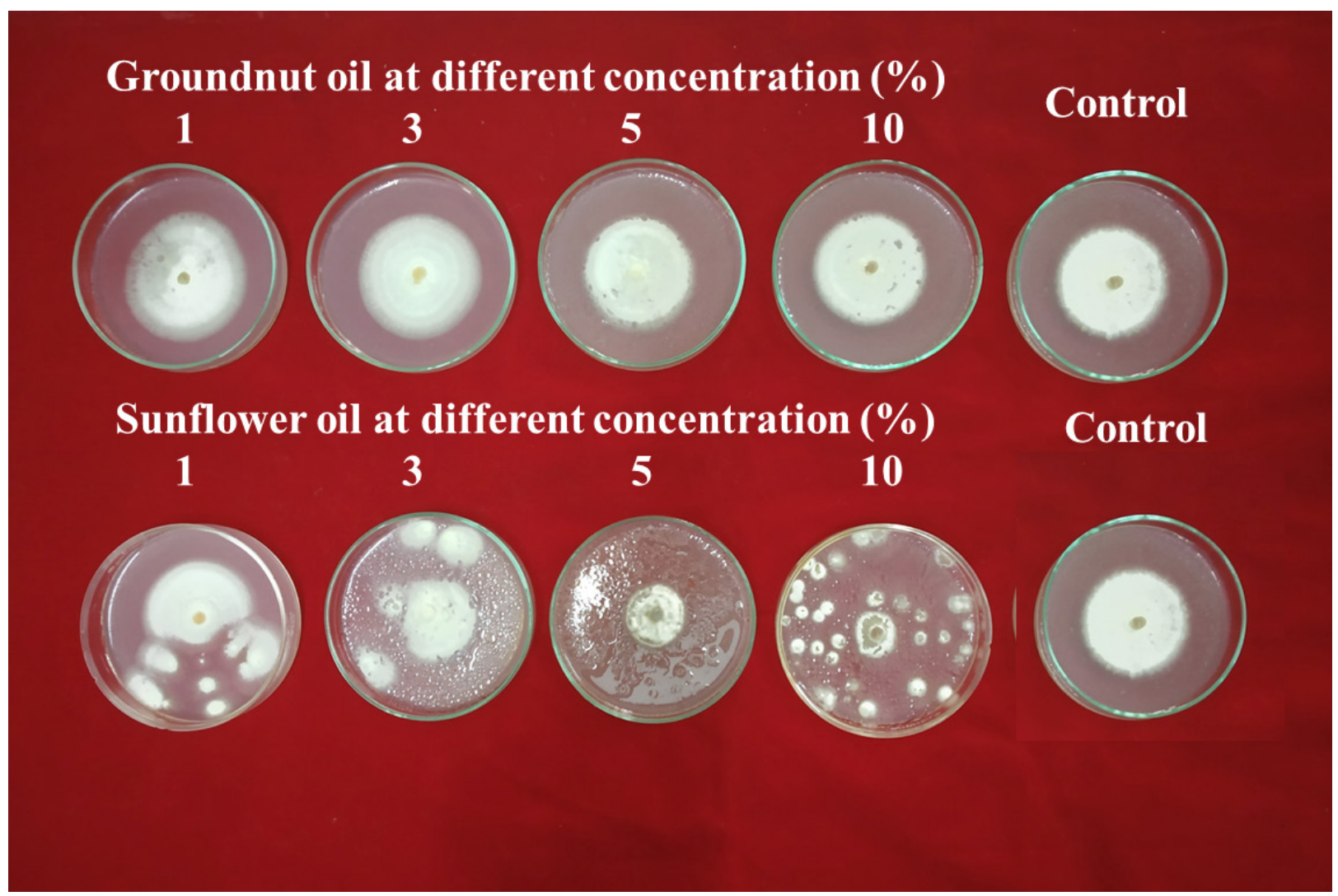

Fig 1. Compatibility of Beauveria bassiana (MK918495) with different concentrations of groundnut and sunflower oil 




Fig 2. Oil in water formulation of Beauveria bassiana(MK918495)



Fig 3. Oil based formulation of Beauveria bassiana(MK918595) 


\section{ACKNOWLEDGEMENT}

The facilities extended by ICAR-AINP Acarology Unit, Insectary, Department of Agricultural Entomology, Tamil Nadu Agricultural University, Coimbatore -641 003 for carrying out the above work is highly acknowledged.

\section{REFERENCES}

Agarwal R, Choudhary A, Tripathi N, Patil S, Agnihotri S, Bharti D. 2012. Biopesticidal formulation of Metarhizium anisopliae effective against larvae of Helicoverpa armigera. J. Biofertil Biopestici. 3:3. https://doi.org/10.4172/2155-6202.1000120

Alves SB, Rossi LS, Lopes RB, Tamai MA, Pereira RM. 2002. Beauveria bassiana yeast phase on agar medium and its pathogenicity against Diatraea saccharalis (Lepidoptera: Crambidae) and Tetranychus urticae (Acari:Tetranychidae). J. Invertebr. Pathol. 81:70-7. https://doi.org/10.1016/S0022-2011(02)00147-7

Athisintha S, Manimegalai S, Vishnupriya R, Muthulakshmi P, Nithya PR. 2019. Infection process and pathogenecity of Beauveria bassiana (Balsamo) Vuillemin against Tetranychus urticae Koch. Ann Pl Protec Sci. 27(2):1949. https://doi.org/10.5958/0974-0163.2019.00040.5

Baptiste SJ, Bloem K, Reitz S, Mizell R. 2003. Use of radiation to sterilize two-spotted spider mite (Acari:Tetranychidae) eggs used as a food source for predatory mites. Fla Entomol. 86(4):389-95. https:// doi.org/10.1653/0015-4040(2003)086[0389:UORTST] 2.0.CO;2

Bateman R, Carey M, Moore DE, Prior C. 1993. The enhanced infectivity of Metarhizium flavoviridae in oil formulations to desert locusts at low humidities. Ann Appl Biol. 122(1):145-52. https://doi. org/10.1111/j.1744-7348.1993.tb04022.x

Batta Y. 2003. Production and testing of novel formulations of the entomopathogenic fungus Metarhizium anisopliae (Metschinkoff) Sorokin (Deuteromycotina: Hyphomycetes). Crop Prot. 22 (2):415-22. https://doi. org/10.1016/S0261-2194(02)00200-4

Butt TM, Jackson C, Magan N. 2001. Fungi as biocontrol agents: progress problems and potential. London:CABI. https://doi.org/10.1079/9780851993560.0000

Chandler D, Davidson G, Jacobson RS. 2005. Laboratory and glasshouse evaluation of entomopathogenic fungi against the two-spotted spider mite, Tetranychus urticae (Acari:Tetranychidae), on tomato, Lycopersicon esculentum. Biocontrol Sci Technol. 15(1):37-54. https://doi.org/10.1080/09583150410001720617

Chavan B, Kadam J, Saindane Y. 2009. Bioefficacy of liquid formulation of Verticillium lecanii against Aphis gossypii. Int J Plant Prot. 2(1):73-6.

Croft B, Hoyt S, Westigard P. 1987. Spider mite management on pome fruits, revised: Organotin and acaricide resistance management. J Econ Entomol. 80(2):304-11. https://doi.org/10.1093/jee/80.2.304

Gadhave AIJSR. 2014. Determination of hydrophiliclipophilic balance value. International $J$ Sci Res. 3(4):573-5.

Gatarayiha MC, Laing MD, Miller RM. 2010. Effects of adjuvant and conidial concentration on the efficacy of Beauveria bassiana for the control of the two spotted spider mite, Tetranychus urticae. Exp Appl Acarol. 50(3):217-29. PMid: 19763849. https://doi. org/10.1007/s10493-009-9307-6

Gillespie A, Crawford E. 1986. Effect of water activity on conidial germination and mycelial growth of Beauveria bassiana, Metarhizium anisopliae, Paecilomyces spp. and Verticillium lecanii. In Samson, R. A., Vlak, J. M., and Peters, D. (Eds.), Fundamental and Applied Aspects of Invertebrate Pathology: 254.

Griffin WC. 1954. Calculation of HLB values of non-ionic surfactants. J Soc Cosmet Chem. 5:249-56.

Gupta SK. 2012. Handbook, injurious and beneficial mites infesting Agri-horticultural crops in India and their management. Nature Books: New Delhi. p. 362.

Kaaya GP, Hedimbi M. 2012. The use of entomopathogenic fungi, Beauveria bassiana and Metarhizium anisopliae, as bio-pesticides for tick control. Int $J$ Agric Sci. 2(6):245-50.

Khachatourians GG, Qazi SS. 2008. Entomopathogenic fungi: Biochemistry and molecular biology. Human and animal relationships'. Springer: Berlin. 33-61. https://link. springer.com/chapter/10.1007/978-3-540-79307-6_3. https://doi.org/10.1007/978-3-540-79307-6_3

Jeppson LR, Keifer HH, Baker EW. 1975. Mites injurious to economic plants: University of California Press. PMid: 1103278. p. 589. https://doi. org/10.1525/9780520335431 
Luz C, Batagin I. 2005. Potential of oil-based formulations of Beauveria bassiana to control Triatoma infestans. Mycopathologia. 160(1):51-62. PMid: 16160769. https://doi.org/10.1007/s11046-005-0210-3

Manivannan A, Sridhar RP, Kamalakannan A, Ganapathy N, Karthikeyan S. 2018. In vitro efficacy of bio control agents against cotton leaf hopper, Amrasca biguttula biguttula (Ishida) (Homoptera: Cicadellidae). Int $J$ Curr Microbiol App Sci. 7(9):2026-31. https://doi. org/10.20546/ijcmas.2018.709.245

Mondel M, Ara N. 2006. Biology and fecundity of the two spotted spider mite, Tetranychus urticae Koch.(Acari: Tetranychidae) under laboratory conditions. J Life Earth Sci. 1:43-7.

Moore D, Prior C. 1993. The potential of mycoinsecticides. Biocontrol News and Information. 14(2):31. https:// www.cabdirect.org/cabdirect/abstract/19931170567

Oatman E, McMurtry J, Shorey H, Voth V. 1967. Studies on integrating Phytoseiulus persimilis releases, chemical applications, cultural manipulations and natural predation for control of the two-spotted spider mite on strawberry in southern California. J Econ Entomol. 60(5):1344-51. https://doi.org/10.1093/jee/60.5.1344

Olmert I, Kenneth RG. 1974. Sensitivity of the entomopathogenic fungi, Beauveria bassiana, Verticillium lecanii and Verticillium sp. to fungicides and insecticides. Environ Entomol. 3(1):33-8. https:// doi.org/10.1093/ee/3.1.33

Prior C, Jollands P, Le Patourel G. 1988. Infectivity of oil and water formulations of Beauveria bassiana (Deuteromycotina:Hyphomycetes) to the cocoa weevil pest Pantorhytes plutus (Coleoptera: Curculionidae).
$J \quad$ Invertebr Patholo. 52(1):66-72. https://doi. org/10.1016/0022-2011(88)90103-6

Prithiva JN, Ganapathy N, Jeyarani S. 2017. Efficacy of different formulations of Beauveria bassiana (Bb 112) against Bemisia tabaci on tomato. J Entomol Zool. 5(4):1239-43.

Saik J, Lacey L, Lacey C. 1990. Safety of Microbial Insecticides by Laird Marshall and Elizabeth W Davidson (eds). CRC Press Boca Raton. 115-32.

Simmonds S. 1971. Observations on the possible control of Tetranychus urticae on strawberries by Phytoseiulus persimilis. Plant Pathol. 20(3):117-9. https://doi. org/10.1111/j.1365-3059.1971.tb00526.x

Safeena S, Thangam M, Devi SP, Desai A, Singh N. 2015. Ready reckoner on cultivation of tuberose. Technical Bulletin: ICAR-Central Coastal Agricultural Research Institute (Indian Council of Agricultural Research), Goa, India.

Sardana H, Bambawale O, Kadu L, Singh D. 2005. Development and validation of adaptable IPM in okra through farmers' participatory approach. Ann Pl Protec Sci. 13(1):54-9.

Shang Y, Feng P, Wang C. 2015. Fungi that infect insects: Altering host behavior and beyond. PLoS Pathog. 11(8):e1005037. PMid: 26248013 PMCid: PMC4527712. https://doi.org/10.1371/journal. ppat. 1005037

Visalakshy PG, Krishnamoorthy A, Kumar AM. 2006. Compatibility of plant oils and additives with Paecilomyces farinosus, a potential entomopathogenic fungus. J Food Agric Environ. 4(1):333. 